\author{
Marlene de Fáveri \\ Universidade do Estado de Santa Catarina
}

\author{
Teresa Adami Tanaka \\ Universidade do Estado de Santa Catarina
}

\title{
Divorciados, na forma da lei: discursos jurídicos nas ações judiciais de divórcio em Florianópolis (1977 a 1985)
}

Resumo: Este artigo pretende discorrer sobre os primeiros processos de divórcio (1977 a 1985), possibilitados pela Lein. 6.515, de 26.12.1977 (a chamada Lei do Divórcio), em Florianópolis, através de pesquisa efetuada na Divisão de Arquivo e Memória do Poder Judiciário, em Santa Catarina. E, perceber como, apesar dos discursos apelativos das instituições a esse recurso jurídico (principalmente a Igreja Católica e as entidades a ela ligadas), que apregoavam o perigo da dissolução da família e dos valores tradicionais a ela agregados, tal lei veio, de modo geral, legalizar práticas familiares já estabelecidas. Também analisar como os casais, separados há muitos anos e vivendo uma segunda união, solicitavam o divórcio com o objetivo de regularizar sua situação civil, vivida, até aquele momento, à margem da lei. Observando os discursos jurídicos, nota-se a reprodução de valores prescritos a um e outro gênero e as relações de poder subjacentes nesses enunciados.

Palavras-chave: processos de divórcio; discursos jurídicos; relações de gênero e familiares.

Copyright (c) 2010 by Revista Estudos Feministas.

1 Projeto O divórcio nas tramas da Lei: processos judiciários em Florianópolis, 1977 a 1985. PROBIC/UDESC, 2006-2008.

2 Mais informações podem ser obtidas no site do Poder Judiciário de Santa Catarina <http:// www.tj.sc.gov.br/>.
Este artigo é resultado de uma pesquisa intitulada $O$ divórcio nas tramas da lei: processos judiciários em Florianópolis, 1977 a 1985,' realizada no Arquivo Central do Poder Judiciário de Santa Catarina - Divisão de Arquivo e Memória Judiciária,$-{ }^{2}$ para quantificar os processos judiciários de divórcio abertos em Florianópolis, no período citado, percebendo o tipo da ação, a classe social dos requerentes e requeridos, a forma da ação (se consensuais ou litigiosos, se de transformação de desquite em divórcio) e o motivo da ação. A partir desses dados, analisamos os 
discursos jurídicos que aparecem nesses processos, os pontos que remetem à reflexão na categoria "gênero", as possíveis mudanças nos arranjos familiares e a forma como os juristas conduzem os processos, bem como as construções culturais que aparecem nos discursos e suas implicações nos processos.

O arquivo do Poder Judiciário constitui-se em um local de guarda de importantes fontes de pesquisa para historiadores por conter o registro de ações judiciais das diferentes áreas do direito que integram o Tribunal de Justiça (da Família, Cível, Penal, Comercial etc.). Além disso, o acesso nos foi permitido com demonstração de profissionalismo, prestimosa atenção e confiança da parte de toda a equipe de funcionários daquela Divisão do Tribunal de Justiça de Santa Catarina.

A pesquisa foi iniciada em setembro de 2007, quando o acervo do arquivo estava em fase de catalogação digital, mas os documentos mais antigos lá guardados ainda não haviam passado por essa providência. Tivemos acesso às caixas que continham os processos do período que abarca os primeiros processos de divórcio em Florianópolis, ou seja, de dezembro de 1977 em diante. As caixas contêm, em ordem numérica e cronológica, todos os processos das Varas da Família, Órfãos e Sucessões, além de divórcios e separações judiciais, ações de investigação de paternidade, inventários, ações de tutela e curatela, alimentos, emancipação de menores, alvarás, interdições etc.

Foram pesquisados os processos de divórcio e alguns de separação judicial e separação de corpos, de 1977 até 1985. Em 1977 houve o protocolo de três pedidos de divórcio, já que a Lei n. 6.515 foi aprovada em 26 de dezembro daquele ano e a homologação só aconteceu a partir de janeiro de 1978. No total, analisamos o conteúdo de 542 processos, sendo 136 do ano de 1978; 131 de 1979; 134 de 1980; 123 de 1981; e mais 18 processos de 1982 a 1985, a título de amostragem, já que não havia tempo para efetuar as anotações do total até 1985, como estava previsto no projeto de pesquisa. Dos anos de 1982 e 1983 efetuamos a compilação dos dados básicos sobre tipo e natureza das ações de divórcio, e a estatística básica dos anos de 1984 e 1985 foi obtida nos livros 22 e 23 do Instituto Brasileiro de Geografia e Estatística (IBGE) em Florianópolis, pois é só a partir de 1984 que o instituto de pesquisa passou a compilar separações judiciais e divórcios nas estatísticas do item Registro Civil (Gráfico 1). 
GRÁFICO 1 - PROCESSOS DE DIVÓRCIO: TOTAL POR ANO E POR TIPO DE AÇÃO



Quando o casal já estava desquitado - há pelo menos três anos -, o processo era denominado ação de conversão em divórcio. Quando estava separado de fatohá pelo menos cinco anos -, era chamado ação de divórcio direto. É consensual quando o casal apresenta consentimento mútuo para o pedido, e não consensual no caso em que o pedido inicial é apresentado por só um dos cônjuges, mas poderá ser transformado em consensual se houver acordo entre os cônjuges. Notamos o Gráfico 2:

GRÁFICO 2 - QUANTIDADE DE PROCESSOS POR TIPO E NATUREZA DA AÇÃO

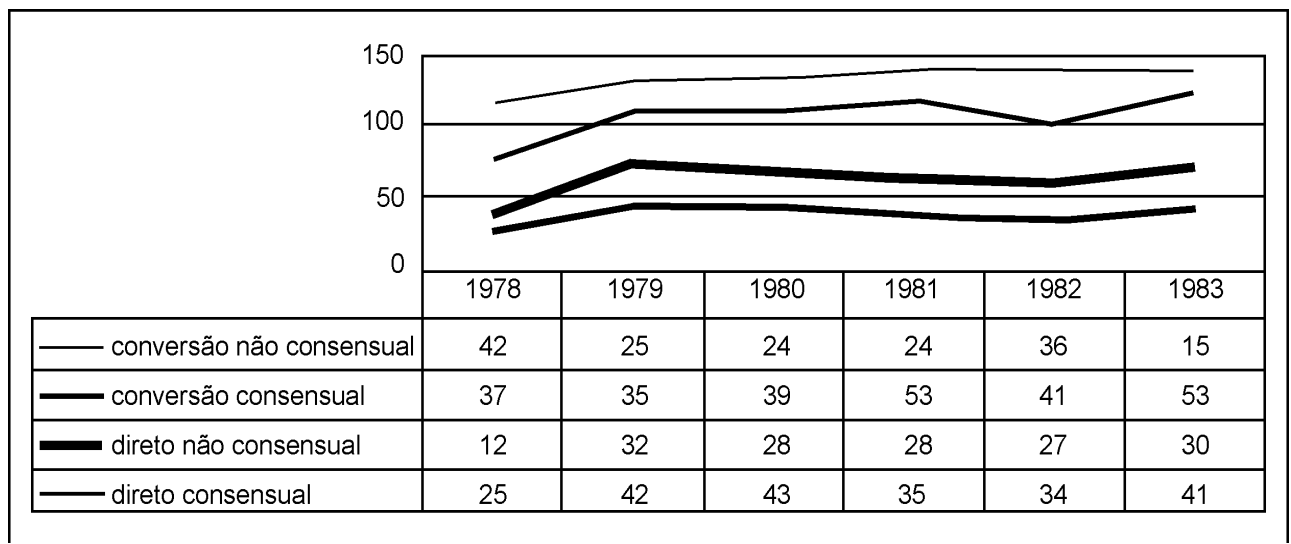

Depois das anotações de dados dos processos de divórcio, da transcrição seletiva, da elaboração de tabelas estatísticas e gráficos, de pesquisas eletrônicas e de muitas leituras, a dificuldade esteve em conseguir relatar todo 0 resultado da pesquisa efetuada em poucas páginas, em 
${ }^{3}$ O caderno especial " 30 Anos de divórcio no Brasil”, publicado em 24 de junho de 2007, trouxe entrevistas com a primeira mulher a se divorciar no Brasil e com os filhos e a viúva do senador Carneiro. virtude do material denso e das amplas possibilidades de análise. Uma pesquisa sobre divórcio nos coloca frente aos instigantes caminhos que percorrem o campo do Direito de Família, com peculiaridades que nos conduzem a uma multiplicidade de problemas a serem equacionados e a exigirem uma seleção criteriosa e delicada.

Quem seriam os sujeitos dos processos verificados? Quais representações sobre os papéis de gênero podem ser percebidas nos vários discursos contidos nos autos judiciais? Haveria referência a conflitos e violências domésticas? Mudanças no perfil demográfico das famílias? Alteração nos padrões de comportamento? Permanências? Qual a principal contribuição da Lei do Divórcio (Lei n. 6.515/77) para a situação social/civil daqueles casais/famílias? As lutas feministas (tão fortes naquela década da discussão e aprovação da lei) estariam de alguma forma enunciadas nas falas dos atores sociais envolvidos?

Os gráficos que apresentamos foram construídos com os dados registrados durante a pesquisa: tipo e natureza da ação; idade de homens e mulheres ao casar e no pedido de divórcio; tempo de casamento; número de filhos, guarda e direito de visitas; pensão alimentícia; alteração do nome da mulher. Entendemos que sejam bastante ilustrativos para a compreensão das inferências apontadas ao longo do trabalho e representam os caminhos percorridos na busca empreendida nesta pesquisa. Os nomes serão omitidos, tendo em vista o caráter sigiloso dos processos judiciais dessa natureza, e optou-se por citar apenas pela categoria "marido/esposa", "homem/mulher", "advogado", "promotor", "juiz", "testemunha" etc.

Os estudos sobre divórcio ainda são em pequeno número no Brasil, certamente por se tratar de tema da história recente do país, porém representam um campo de possibilidades de estudos históricos desafiador. $O$ ano de 2007 marcava os 30 anos de aprovação do divórcio no Brasil, e a "luta" do senador Nelson Carneiro foi relembrada, analisada, resenhada. Vários jornais dedicaram páginas especiais a esse tema, como fez a Folha de S.Paulo, em seu Caderno Mais!, ${ }^{3}$ e muitas reportagens televisivas e artigos em meio eletrônico trataram a respeito do tema. Reverberava, nessas publicações, a alteração do Código de Processo Civil, por força da Lei n. 11.441, de 05 de janeiro de 2007, que veio facilitar os processos de separações e divórcios, possibilitando serem feitos através de registro em cartórios locais, sem a necessidade de ação judicial. Se, em 1977, o assunto invadiu as páginas dos jornais do país inteiro, comoveu plateias e oportunizou uma das mais polêmicas discussões nas esferas parlamentares, bem como nas hostes da Igreja Católica, neste momento foi mais um ato 
4 Geraldo Tadeu Moreira MONTEIRO, 2003.

5 Nelson CARNEIRO, 1977.
${ }^{6}$ O APÓSTOLO, 15 set. 1951, p. 3.

${ }^{7}$ Em 1890, o Congresso Constituinte refutou emendas divorcistas apresentadas por Lopes Trovão, Leopoldo Bulhões e Guimarães Natal. governamental conhecido pela população por meio da imprensa, sem abaixo-assinados nem passeatas.

A aprovação da Emenda Constitucional n. 9, de 28 de junho 1977, e da Lei n. 6.515, de 26 de dezembro de 1977, que instituiu o divórcio no Brasil, está inserida no processo histórico de profundas mudanças no Direito de Família verificadas nos últimos 50 anos. Por seu lado, essas mudanças radicais traduzem uma nova realidade vivida pela sociedade brasileira, no âmbito das relações familiares, e ocorreram em meio a intensos debates políticos entre diversas correntes filosóficas e ideológicas que exerceram influência na elaboração das políticas familistas do Estado brasileiro, que Monteiro define como o processo de codificação civil na instauração da ordem liberal conservadora no Brasil. ${ }^{4}$

A influência da Igreja Católica perpassou todo esse processo e marcou forte presença na oposição aos projetos divorcistas, reiterando o seu desejo na preservação do modelo de família nuclear, monogâmica, heterossexual e indissolúvel como base da sociedade e como a única possível. Nelson Carneiro (1910-1996), deputado federal e senador cuja carreira política ficou marcada pela longa campanha em favor do divórcio no Brasil ou, como ele gostava de dizer, "em defesa da família", estabeleceu acirradas discussões com representantes daquela instituição religiosa e deixou registrados os embates entre divorcistas e antidivorcistas em livro publicado ainda em 1977, logo após a aprovação da Emenda Constitucional, quando a Lei n. 6.515 ainda era um "projeto de lei". ${ }^{5}$ Seus projetos de lei a favor do divórcio, apresentados desde 1951, provocaram intensas manifestações da Igreja Católica publicadas em jornais como O Apóstolo, editado pela Cúria Metropolitana de Florianópolis e que trazia mensagens como a seguinte:

[...] Campanha mais ou menos cerrada, conforme a ocasião e a moda, em favor do divórcio. Desejam para o Brasil esta calamidade, este flagelo social, esta chaga da civilização paganizada. [...] mulheres fúteis e levianas e os maridos infiéis e gozadores de vida sem nenhum senso de responsabilidade. [...] Além do mais, o exemplo da América do Norte e os filmes de Hollywood, exercem influência perniciosa sobre nossa gente. [...] só querem imitar os EE.UU. nas patifarias e imoralidades [...] e [...] no divórcio! Ser divorcista vem a ser uma espécie de elegância tipo U.S.A.!

[...] A lei é severa! Pelo evangelho não há divórcio. Não há divórcio! ${ }^{6}$

Embora a Igreja Católica não possa ser apontada como a única, ${ }^{7}$ certamente foi a principal reserva de oposição à inclusão da dissolubilidade matrimonial nas 
${ }^{8}$ Sobre as correntes filosóficas na formação do pensamento dos civilistas brasileiros em relação à família, ver MONTEIRO, 2003, cap. 6.

\begin{abstract}
${ }^{9}$ Ver Roderick PHILLIPS, 1991. O autor analisa as mudanças nas leis do divórcio no mundo ocidental (Europa e América do Norte), "dentro dos mais amplos contextos sociais, econômicos, políticos e culturais" (p. 11), e como as leis muitas vezes coincidiram com mudanças políticas/ideológicas nos países abordados.
\end{abstract}

10 MONTEIRO, 2003, p. 30.

11 Joan SCOTT, 1990, p. 15.

${ }^{12}$ Michel FOUCAULT, 2007, p. 45.

${ }^{13}$ Pierre BOURDIEU, 1996. leis que regulam o Direito de Família. ${ }^{8} \mathrm{O}$ fato é que a indissolubilidade do vínculo conjugal foi quebrada apenas em 1977, quase 100 anos depois da declaração de separação entre Igreja e Estado em nosso país, enunciada na primeira constituição republicana, em 1891. Entretanto, o Brasil não pode ser citado como o último país onde essa influência persistiu. Por exemplo, na Espanha o divórcio só voltou a ser legalizado em 1981 (a legislação de 1932 havia sido suprimida em 1939) e a Irlanda ainda se constitui num reduto de resistência ao divórcio. ${ }^{9}$

Segundo juristas, a Lei do Divórcio foi aprovada sob um clima de moralismo que permeava a sociedade brasileira a pregar que o divórcio seria o fim da família. E o fim da família - base da sociedade, segundo a Constituição Federal -, para a maioria dos civilistas brasileiros, significaria a ruína de todo o suporte social, portanto a desgraça para o Estado brasileiro. No longo caminho percorrido pelo processo de produção do Direito de Família, Geraldo Tadeu Monteiro analisa que esse campo do direito constituiu-se em "instrumento privilegiado de imposição de uma ordem de gênero estatizada e fundada na hierarquia entre os sexos", instaurando, no próprio texto das leis, a desigualdade, observando que "ao repartir estatutos e sancionar os papéis, o Direito reproduz o jogo das estratificações sociais". ${ }^{10}$

Para perceber como os papéis de gênero estão socialmente construídos e normatizados pelos discursos de gênero contidos nos conceitos jurídicos do casamento, nos direitos e deveres dos cônjuges, no regime de bens, no nome de família do qual fala Monteiro, está sendo utilizada a categoria de análise "relações de gênero", dentro da concepção de Joan Scott, que nos diz que "os historiadores devem antes de tudo examinar as maneiras pelas quais as identidades de gênero são realmente construídas e relacionar seus achados com toda uma série de atividades, de organizações e representações sociais historicamente situadas". ${ }^{11}$

$\mathrm{Na}$ análise dos discursos jurídicos e entendendo o campo jurídico como um dos sistemas de sujeição do discurso "que garantem a distribuição dos sujeitos que falam nos diferentes tipos de discurso", composto de regras que organizam, controlam, selecionam e redistribuem a produção de novos discursos, na perspectiva proposta por Foucault, ${ }^{12}$ observa-se nos processos que os discursos colaboram para a construção de uma nova categoria jurídica: "os divorciados", identidade legitimada pela eficácia simbólica do saber jurídico exercido pelos diferentes atores sociais, investidos do poder de interpretar os textos especializados (advogados, promotores públicos, oficiais de justiça, juízes) e portadores de autoridade e da linguagem autorizada, temas tratados por Bourdieu. ${ }^{13}$ 
${ }^{14}$ Antonio Macedo de CAMPOS, 1984.

${ }^{15}$ CARNEIRO, 1977, p. 27.

${ }^{16}$ Ver Ana Elizabeth Lapa Wanderley CAVALCANTI, 2008.

17 Luzia Aurelia CASTAÑEDA, 2008.
Os trechos das argumentações de alguns processos transcritos neste artigo revelam os embates discursivos travados entre os divorciandos e as divorciandas, representados por seus advogados e que se expõem ao veredicto dos promotores públicos e dos juízes visando obter a condição jurídica de divorciados, ou seja, a regularização de uma situação civil ilegítima. Homens e mulheres são confrontados com os papéis determinados pelas prescrições sociais e por meio das descrições que emergem nas falas de advogados, promotores e juízes no desenrolar das ações judiciais: filhos, paternidade, maternidade... deveres e direitos. Como se constrói o universo familiar regulado pelo Estado através do Direito de Família? Instituição, contrato civil, sentimentos, obrigações. Casamentos, famílias: lugares de administração de conflitos normatizados e mediados pelos portadores de saber jurídico.

A Emenda Constitucional n. 9 foi promulgada no dia 28 de junho de 1977. No entanto, o texto constitucional não é "autoaplicável", ensinam os juristas, isto é, necessita de regulamentação através de lei complementar. ${ }^{14}$ Assim, após a inclusão do divórcio no texto constitucional, longos embates se registraram até a aprovação da Lei n. 6.515, de 26 de dezembro de 1977, a chamada Lei do Divórcio, que regulamentou juridicamente o que determinava a Emenda Constitucional n. 9. O ano de 1977 marcou o contexto político brasileiro certamente em virtude da alteração do art. 175 da Constituição do país, retirando o princípio da indissolubilidade do matrimônio, incluída no texto constitucional em 1934, por força de expressiva influência de parlamentares ligados a instituições católicas, e que, para Nelson Carneiro, representava um dogma "em termos mais rigorosos, [...] do que na própria legislação canônica". ${ }^{15}$

Diversos especialistas observam que a existência, ainda hoje, da figura da separação judicial como prérequisito para a obtenção do divórcio representa um verdadeiro "pleonasmo jurídico" e se deve ao conservadorismo da sociedade e da significativa influência da Igreja Católica na elaboração da Lei do Divórcio. ${ }^{16}$ Por outro lado, a Igreja Católica não se constituiu como a única reserva de conservadorismo contida na lei. O casamento monogâmico também era a forma sugerida como única possível pelos defensores das teorias eugênicas, como informa Luzia Aurelia Castañeda. ${ }^{17}$ Exigências como o exame pré-nupcial, controle de casamentos inter-raciais e consanguíneos, impedimentos para a nupcialidade de doentes/deficientes físicos e mentais, estão entre as restrições das campanhas eugênicas e sanitaristas e foram normas e tabus que estiveram presentes nos textos que regulam 0 Direito de Família, segundo a autora. 
${ }^{18}$ Ver FOLHA DE S.PAULO, 27 mar. 1994 , P. B-1.

19 Marilange NONNENMACHER, 2002.

20 Ver Reinaldo Lindolfo LOHN, 2008.

\footnotetext{
${ }^{21}$ Ver banco de dados da Folha, em Acervo de Jornais, disponível no site <wwwl .folha.uol.com.br $>$.

22 Ver Rosângela DIGIOVANNI, 2003.
}

O Brasil, sob o regime militar instaurado desde 31 de março de 1964, vivia em 1977 um clima de esperança de redemocratização, a chamada "distensão política", prometida pelo Presidente Ernesto Geisel ao assumir o governo em 1974, após os "anos de chumbo" do governo do General Emílio Garrastazu Médici (1969-1974). O tema da modernização do país era amplamente utilizado pelos governantes e estava sempre presente nas discussões naquele período: o Brasil não seria mais um país subdesenvolvido, agora passaria a ser um país "em desenvolvimento". ${ }^{18}$

A cidade de Florianópolis, nos anos 1970, caminhava no compasso dos discursos desenvolvimentistas e passava por um "intenso processo de remodelação e expansão", ${ }^{19}$ com grandes obras de intervenção urbana, como a construção da Ponte Colombo Sales e do aterro da Baía Sul, a abertura de vias expressas, em ritmo acelerado de mudanças na ocupação dos espaços e alterando a paisagem urbana para uma modernização da cidade, que, sendo capital do estado, tinha, até a década de 1970, uma economia urbana apoiada, principalmente, na sua função administrativa e buscava alterar essa situação marginal em relação a outras regiões do estado de Santa Catarina e ao panorama nacional. ${ }^{20}$

Dentro desse contexto, os debates sobre direitos humanos se avolumavam e pressionavam por liberdade de expressão e denunciavam as arbitrariedades cometidas pelo regime militar no combate às ideologias de esquerda. Censura e repressão, dois aspectos fortes dos militares "linhadura", tiveram um início de afrouxamento a partir de 1975. Os meios de comunicação expandiam-se. Falava-se em liberação sexual. As mulheres apareciam no cenário público: nas universidades, no mercado de trabalho, nas passeatas A discussão da Emenda Constitucional n. 9 aconteceu em meio a essas nuances políticas e profundas mudanças sociais em que os dois partidos existentes na época - ARENA e MDB - dividiam o palco político e, apesar da nítida divisão entre situação (ARENA) e oposição (MDB) nos assuntos referentes à Ditadura Militar, no momento da votação da Emenda n. 9 não houve oposição de acordo com a filiação partidária, como podemos deduzir pela lista de votos publicada nos jornais da época. ${ }^{21}$

Durante a votação registrou-se presença de público nas galerias do Congresso, composto de membros de campanhas pró-divórcio de diversas cidades do Brasil. ${ }^{22} \mathrm{O}$ fato chegou a ser considerado inusitado diante do contexto político vivido, de restrição a manifestações populares. Vaias acompanhavam os votos contra o divórcio e aplausos, os favoráveis. A sessão iniciou-se na manhã do dia 15 de junho de 1977 e só foi encerrada à uma hora do dia 16, 
${ }^{23}$ Processo 158/80, de 20.03.1980.

com a declaração de aprovação da Emenda Constitucional n. 9, de autoria dos senadores Nelson Carneiro (MDB/RJ) e Accioly Filho (ARENA/PR), que instituiu o divórcio no Brasil.

A principal arguição dos divorcistas para arregimentar a adesão à inclusão da dissolubilidade do vínculo matrimonial nas leis do país, que aconteceu com a aprovação da Emenda Constitucional n. 9 e com a Lei n. 6.515, de 26.12.77, foi construída no sentido de atender a uma parcela de famílias brasileiras já desfeitas e sem possibilidade de reconstituição e, por outro lado, regularizar aquelas construídas dentro dos princípios do amor conjugal, mas na ilegitimidade jurídica denominada concubinato. A intenção dos legisladores, ao construir o corpo da Lei do Divórcio, buscava dar amparo legal para resolver questões pertinentes ao patrimônio familiar e também aos direitos previdenciários (seguros, pensões, pecúlios etc.). Segundo eles, o divórcio viria proporcionar a oportunidade de recomposição familiar $e$, principalmente, dar estabilidade moral às mulheres $e$ reconhecimento civil aos filhos dessas uniões.

Argumentação semelhante e recorrente + separação de fato há muitos anos e existência de uniões informais que necessitavam de regulamentação jurídica + foi verificada nos processos de divórcio, das Varas da Família, Órfãos e Sucessões, da Comarca de Florianópolis. Tratava-se de casais "unidos apenas juridicamente, sem qualquer espécie de intercâmbio pessoal", ${ }^{23}$ como observou um juiz ao proferir sua sentença. Até porque a lei só dispunha a possibilidade de solicitar o divórcio aos casais previamente separados, e os gráficos inseridos a seguir ilustram essa afirmação. Podemos perceber na diferença apresentada entre o tempo realmente vivido em comum (Gráfico 3) e o tempo decorrido até a data do processo de divórcio (Gráfico 4) a evidência de separações sedimentadas há longos anos para cuja solução jurídica a Lei do Divórcio iria contribuir. 
GRÁFICO 3 - TEMPO DE CASAMENTO, DE ACORDO COM O TEMPO DE CONVIVÊNCIA INFORMADO NA PETIÇÃO INICIAL

\begin{tabular}{|c|c|c|c|c|c|c|c|c|c|c|c|}
\hline & \multicolumn{1}{|c|}{ até 2} \\
anos & 3 & 4 & 5 & 6 & 7 & 8 & 9 & $\begin{array}{c}10 \text { a } \\
14\end{array}$ & $\begin{array}{c}15 \text { a } \\
19\end{array}$ \\
+ \\
\hline
\end{tabular}

\section{GRÁFICO 4 - TEMPO DE CASAMENTO NA DATA DO DIVÓRCIO}

\begin{tabular}{|c|c|c|c|c|c|c|}
\cline { 2 - 7 } & \multicolumn{5}{|c|}{} \\
\hline & 6 anos & 7 a 10 anos & 11 a 14 anos & 15 a 19 anos & 20 a 30 anos & $\begin{array}{c}\text { mais de } 30 \\
\text { anos }\end{array}$ \\
\hline & 7 & 16 & 18 & 28 & 30 & 21 \\
\hline -1981 & 3 & 19 & 15 & 28 & 48 & 21 \\
\hline -1980 & 3 & 12 & 26 & 20 & 27 & 30 \\
\hline-1979 & 3 & 13 & 29 & 24 & 28 & 33 \\
\hline
\end{tabular}

${ }_{24}$ Processo 616/79, de 04.10.1979.

Assim, a principal motivação para os pedidos de divórcio era a necessidade, ou o desejo, de legalizar novas uniões vividas "de fato" pelos casais envolvidos e os efeitos jurídicos inerentes (com os filhos dessas uniões, o direito sucessório e de herança etc.), desejos estes recorrentes nos processos pesquisados. As informações sobre a motivação dos pedidos são redundantes:

É que a situação hoje existente, - dez filhos da nova união que dura pelo menos mais de quinze anos está a reclamar medida judicial que a regularize diante da Lei Civil. [.... ${ }^{24}$

Concorda com a pretensão da Suplicante de ver a situação de ambos legalizada, uma vez que vivem 
${ }^{25}$ Processo $25 / 80$, de 21.01 .1980

${ }^{26}$ Processo 7.322, de 10.05.1978. vidas totalmente independentes, tendo o Suplicado constituído nova família, vivendo há longos anos com uma companheira com a qual tem filhos [...]. ${ }^{25}$ Desta forma, não existe nenhuma possibilidade, em vista do longo tempo de separação, da reconstituição do lar, o qual, tudo leva a crer, está para sempre desfeito. Assim, resta somente dar forma jurídica a uma situação de fato há muito existente. $[. . .]^{26}$

Na realidade, esses casais já haviam resolvido suas vidas, à margem da lei. Porém, sujeitavam-se a todo o ritual jurídico exigido para a regularização civil ("pôr em forma"): comparecer frente a um juiz, explicar tudo através de um advogado, depois ratificar que estavam separados, informar que viviam (ou que pretendiam fazê-lo) maritalmente com outros companheiros, apresentar testemunhas, solicitar deferimento etc. $\mathrm{E}$, dentro do ritual exigido, diante dos portadores da capacidade de interpretação dos textos especializados, os discursos dos requerentes revelam estratégias, astúcias e artimanhas com o objetivo de obter sentença favorável e rápida da Justiça e, desse modo, estarem protegidos pela lei. Os advogados, em nome dos requerentes da ação - marido e mulher que desejavam o divórcio -, dirigiam seu discurso à autoridade judicial em nome de seus representados, construindo seu discurso de forma a torná-lo legítimo perante o receptor (juiz de direito), utilizando a "linguagem autorizada" específica para a situação formal, dentro das condições rituais estabelecidas para tornar válido e eficaz o ritual de decretação do divórcio. ${ }^{27}$

Os juízes de direito, em suas sentenças, por seu lado, procuravam valorizar a função social da lei e dos seus representantes, dentro desse processo, considerado imprescindível para o país na sua caminhada em sintonia com o restante do mundo dito civilizado:

[...] Em boa hóra (sic) surgiu a Emenda Constitucional $\mathrm{n}^{\circ} 9$ de 28.06.1977 e, em conseqüência a LEI $\mathrm{n}^{\circ}$. 6.515, de 26/12/1977, instituindo e regulamentando 0 DIVÓRCIO, dando a estas unióes e aos seus filhos uma solução definitiva para a instabilidade legal e social em que se debatiam, fazendo com que o país ingressasse e passasse a admitir $\mathrm{o}$ instituto inserido na legislação da quase totalidade dos países civilizados. ${ }^{28}$

O conceito de civilização surge nos discursos referendando as relações de força simbólicas contidas na lei. A legislação vem conferir "eficácia simbólica", colocar dentro das normas, trazer para a proteção do Estado e "pôr em forma" as uniões constituídas à margem do direito. Enfim, vem inseri-las nas regras das instituições. Assim, segundo Bourdieu, "O direito consagra a ordem estabelecida ao 
${ }^{29}$ BOURDIEU, 1996, p. 237.

${ }^{30}$ Processo 93/79, de 09.03.1979.

${ }^{31}$ BOURDIEU, 2007, p. 224.

32 BOURDIEU, 2007, p. 213.

${ }^{33}$ BOURDIEU, 2007, p. 228-229.

${ }^{34}$ Trecho da sentença de desquite, em 13.05.1976. Processo 509/81, de 20.07.1981. consagrar uma visão desta ordem que é uma visão do Estado, garantida pelo Estado". ${ }^{29}$ Os juízes, no papel de autoridade com capacidade para interpretar os textos jurídicos e de aplicá-los na categoria de verdade, constroem suas sentenças revelando a organização da Justiça segundo uma hierarquia entre as instâncias judiciais e as relações de poder que as permeiam:

[...] Isto posto,

Considerando o direito aplicável à espécie e tudo mais o que dos autos consta, julgo procedente a inicial, e, com fulcro no art. 25, da Lei do Divórcio, converto a separação nesta figura, declarando extinto, destarte, o vínculo conjugal criado com o casamento de [...] e de [...], dizendo-os, doravante, divorciados. (Ass.) Juiz de Direito [...]. ${ }^{30}$

Opera-se, nos processos, um intrincado jogo de relações de poder em que cada um dos agentes envolvidos vai construindo seus discursos de acordo com a versão de verdade que procura fazer valer. Assim, citando Bourdieu, percebemos o quanto "o conteúdo prático da lei que se revela no veredicto é o resultado de uma luta simbólica entre profissionais dotados de competências técnicas e sociais desiguais". ${ }^{31}$ Esses profissionais defrontam sua posição de agentes autorizados com a das instituições que os autorizam, buscando apresentar suas decisões e interpretações na resolução dos conflitos, de maneira a explicitar coerência e rigor na aplicação das normas e dos princípios jurídicos, porém como se isso acontecesse "por uma necessidade simultaneamente lógica e ética". ${ }^{32}$

Percebemos como as desavenças passam pela mediação dos agentes jurídicos e como os requerentes se rendem à "regra do jogo jurídico", aceitando tacitamente a decisão da autoridade encarregada de resolver os conflitos e renunciando ao litígio ${ }^{33}$ "principalmente nos casos em que havia filhos. E assim, nesse outro caso, após longo embate entre o marido e a esposa, no acordo para a separação consensual, constava o compromisso assumido perante a autoridade judicial: "agindo ambos, DESQUITANDO e DESQUITANDA, sempre de forma a minorar ao máximo os efeitos da dissolução da sociedade conjugal, no que aos filhos possa interessar ou afetar". ${ }^{34}$ Deixaram o "dito pelo não dito" e prometeram que procurariam manter o equilíbrio emocional, em nome do amor paternal/maternal. Prometido estava; se foi cumprido, não saberemos.

Outro casal se comprometia diante do juiz: "[...] que sobre a formação moral e intelectual dos filhos, os desquitandos assumem o compromisso de envidarem todos os esforços no sentido de que eles (sic) sejam educados em colégios onde se 
${ }^{35}$ Processo 296/79, de 01.06.1979.

${ }^{36}$ Processo 925/80, de 05.12.1980, caixa 31.

${ }^{37}$ Processo 963/80, de 16.12.1980, caixa 34.

${ }^{38}$ Processo 7.653, de 29.08.1978.

\footnotetext{
${ }^{39}$ Processo 7.653, de 29.08.1978.
}

Ihes incuta o amor ao estudo, à família e o respeito aos princípios cristãos". ${ }^{35}$ Noutro processo, depois de acusações mútuas, o casal, enfim, cedia ao acordo sugerido pelo magistrado, que relatou na sentença declaratória do desquite:

[...] Se censura faz o separando à conduta da separanda como esposa, e a recíproca é verdadeira, não há o menor reparo ou censura, de um ou de outro, como pai e mãe.

[...] Não há litígio em torno da guarda da filha... [...] Até porque, embora separados, não deve o relacionamento pais-filhos sofrer qualquer abalo decorrente da constrangedora situação da qual estes são apenas vítimas. ${ }^{36}$

Percebe-se o esforço do juiz em não se deixar impressionar pelas acusações entre os cônjuges, buscando proferir uma sentença "justa", no sentido dos deveres de um e outro cônjuge como pais, em relação à filha do casal. As referências ao bem-estar moral dos filhos se repete: o representante legal esclarece a motivação para o pedido de divórcio de seu cliente:

O Requerente reside nesta Capital e constituiu nova família com a Dona [...], com quem tem três filhos, todos em idade escolar e freqüentando o Colégio em Capoeiras. Deseja ardentemente regularizar sua situação familiar atravez (sic) do divórcio, enquanto seus filhos ainda são pequenos, mediante novo casamento com a mãe deles. ${ }^{37}$

Os pedidos reiteram o desejo de regularização da situação civil, em nome do bem-estar dos filhos. O advogado, intermediando a causa descrita a seguir, informa que seu cliente vivia com outra mulher, com a qual tinha uma filha e "estando sua companheira em adiantado estado de gravidez; tendo, portanto, sincera intenção de, em futuro próximo, legalizar perante a sociedade sua união com a companheira, que tem sido, de fato, sua esposa". ${ }^{38}$ Porém, a esposa que fora acusada por ele de não cumprir com "deveres domésticos" contestou a ação e expôs outra versão dos fatos, retrucando que ele era depravado, abandonara o lar para viver com outra mulher antes de dois anos de casamento, com o agravante que ela estava esperando o segundo filho do casal: "[...] ao reverso, a ré até hoje se mantém digna, pura e jamais prevaricou em todo esse tempo. Vive para seus dois filhos e para seus velhos e doentes pais, que mantém sob seus cuidados". ${ }^{39}$

Vemos aqui como a mesma arguição produzida por advogados de lados contrários, um a favor do homem/pai/ companheiro que deseja assumir a paternidade e, por isso, solicita o divórcio, outro acusando aquele mesmo homem/ 
${ }^{40}$ BOURDIEU, 2007, p. 250, grifos nossos.

${ }^{41}$ Processo 95/80, de 05.03.1980.

${ }^{42}$ Processo 95/80, de 05.03.1980.

${ }^{43}$ Processo 770/79, de 29.11.1979. pai/ex-marido de no passado ter abandonado a ex-mulher grávida, cria uma contradição partindo do mesmo ponto da lei. Diante do juiz, "os agentes envolvidos num trabalho codificado sabem que podem contar com uma norma coerente e sem escapatória, logo que podem calcular e prever tanto as conseqüências da obediência à regra como os efeitos de sua transgressão", como nos diz Bourdieu. ${ }^{40}$

O não cumprimento das prescrições sociais ao papel masculino dentro do casamento tornava-se argumento decisivo nas falas dos advogados em defesa das esposas, visando pleitear garantias jurídicas com relação à pensão alimentícia dos filhos, ao patrimônio ou ainda como estratégia para obter isenção do pagamento de taxas e custas da ação judicial. Diversas petições registravam essas inferências: "Em dezembro de 1958, quatro anos após a desastrosa união, por motivos desconhecidos, o suplicado saiu de casa, não mais voltando nem mantendo contato com a Requerente ou seu filho, deixando consequentemente de contribuir para os encargos do lar". ${ }^{11}$ O requerido vive, segundo a descrição, "em lugar incerto e não sabido", e ela, "a partir de 1961, passou a viver maritalmente com [...], com quem vive até hoje e a quem seu filho conhece como pai" . ${ }^{42}$ A situação familiar vivida estava consolidada há quase 20 anos, mas o fato de o marido haver abandonado espontaneamente o lar configurava motivo previsto em lei para o pedido de divórcio e a requerente, como cônjuge inocente, não foi onerada no pagamento das taxas do processo.

Nos casos em que o requerido não fosse localizado, entrava em cena a figura do curador do réu, um promotor público nomeado pelo juiz encarregado do caso para verificar os autos do processo e apontar se houvesse irregularidades. Num dos processos o curador examinou os documentos e questionou a veracidade da alegação de abandono, argumentou que os fatos não foram suficientemente esclarecidos e que a autora deveria ter envidado esforços para localizar o réu. O advogado da requerente reiterou as alegações iniciais e retrucou que "Na verdade, a prova maior que a $A$. tentou alcançar seu marido, está na certidão [...] quando foi em busca de alimentos. O R. desapareceu sem deixar vestígios e se preocupar com os três filhos menores e com o quarto que estava por nascer". ${ }^{43}$ Tratava-se do cumprimento de um ritual para legitimar a autoridade chamada a se pronunciar, sujeitando a requerente a apresentar provas do abandono.

Por outro lado, a sugestão da dependência finaceira feminina do "chefe de família" provedor, poderoso, permanecia como recurso apelativo nos discursos dos advogados, que relatavam os fatos à sua maneira: "[...] a requerente e seus filhos ficaram passando sérias privações, 
44 Processo 50/81, de 02.02.1981.

${ }^{45}$ Processo 340/80, de 15.05.1980.

${ }^{46}$ Processo 023.84.900020-6, de 22.08.1984, caixa 6.451.

${ }^{47}$ Processo 7.045, de 28.12.1977.

${ }^{48}$ BOURDIEU, 2004, p. 18.

49 DIGIOVANNI, 2003, p. 87.

${ }^{50}$ Trecho da petição de desquite. Processo 175, de 10.05.1967. obrigando-a a ter que procurar apoio em um companheiro, com o qual vive há alguns anos". ${ }^{44}$ As mulheres, ao aderirem às estratégias possivelmente sugeridas pelos advogados, conformavam-se confusamente ao modelo esposa/ dependente-marido/provedor.

Em outro caso, a esposa utilizava o fato de o marido estar desempregado como motivo para solicitar a separação (que não chegou a se materializar) - "O requerido era pessoa irresponsável, malandro, pouco ligando para o serviço e para a família" - ${ }^{45}$ e pressioná-lo a tomar uma atitude. A estratégia logrou resultado: "Vendo a atitude da mulher, ao tentar a separação caiu na realidade (ainda mais que ama muito seus filhos) e empregou-se. [...] Estando o cônjuge varão trabalhando e responsabilizando-se pela manutenção do lar, cessou o motivo da separação", ${ }^{46}$ informava o advogado, solicitando o arquivamento da ação. Cabe notar que a mulher tinha rendimentos próprios que garantiam o sustento dela e dos filhos (constava nos autos). Entretanto, insistiu para que o marido cumprisse o papel de provedor e, quando isso aconteceu, "cessou o motivo da separação".

A alegação era repetida em outra petição em tom dramático: "A requerente que, com o abandono do cônjuge, indo para lugar incerto e não sabido, passou a arcar com todos os encargos, ficou em situação desesperadora, criando a totalidade dos filhos". ${ }^{47}$ Os discursos jurídicos nesses casos induzem a refletir sobre a cobrança que acontecia entre os cônjuges em relação aos filhos diante da instância jurídica autorizada a decidir sobre seus conflitos familiares, de uma adequação aos papéis sexuais socialmente definidos, ou seja, opera-se a reprodução de uma ordem social que "funciona como uma imensa máquina simbólica que tende a ratificar a dominação masculina". ${ }^{48}$

O modo como essa questão aparece nos discursos jurídicos fundamentando acusações e expondo "a dimensão contratual da relação conjugal" constituída pelo casamento civil, como constata Rosângela Digiovanni, ${ }^{49}$ traz a confirmação da ruptura dos deveres matrimoniais e estabelece motivos legais para a separação. "Tudo isso resultou o desamparo moral e material da Autora e filhos, sendo que, a mesma somente a $1^{\circ}$ de dezembro de 1966 , conseguiu o emprêgo (sic) que ora exerce [...]",50 explicava o advogado, valorizando o caráter da requerente (esse tipo de argumentação servia de estratégia para conseguir isenção no pagamento das custas judiciais da ação).

Entretanto, quando o que estava em jogo era uma pensão alimentícia em favor da mulher, utilizava-se a posição de dependência desta em relação ao (ex-)marido e a ideia do casamento como forma de garantia financeira para ela, nos moldes tradicionais, conforme dizia a petição: 
${ }^{51}$ Processo 578/79, de 13.09.1979.

52 Processo 023.78.000056-3 (cód. Arq.), de 09.08.1983.

53 Processo 023.78.00056-3, de 09.08 .1983 .
"[...] viveu longos anos com o Requerido, sem que houvesse desta união nenhum benefício e nenhuma garantia para o seu futuro". Recebia pensão, mas alegava ser insuficiente e requeria garantias futuras sobre pensão e seguros e as conseguiu. ${ }^{51}$ Há outros casos em que as mulheres dispensaram o direito de receber pensão do ex-marido e depois, ao se depararem com dificuldades financeiras, recorreram a juízo, como neste exemplo:

[...] No momento em que se concretizava legalmente a separação a contestante não previu as necessidades materiais que posteriormente iria ter, motivo porque em poucos meses depois pretendeu pleitear a pensão alimentícia que the tinha sido momentaneamente surrupiada a revelia e em contraposição às determinações legais vigentes. [... $]^{52}$

O iłem "pensão alimentícia (alimentos)" é referência obrigatória nos processos, devendo ser decretada pelo juiz se não houver acordo entre o casal ou ser declarada a dispensa, sempre com a ressalva de "ficando-lhe, no entanto, assegurado o direito de pleiteá-los, quando deles necessitar", ${ }^{3}$ para garantir o cumprimento da lei. Desse modo, percebemos, na análise dos dados, uma incidência majori-tária do iłem "sem pensão" (50\%), significando a dispensa desta ou o indeferimento (poucos casos), que se inter-relaciona com a natureza consensual de grande parte dos processos: a idade dos casais (separação consolidada há vários anos). Esses fatores colaboram para que a pensão seja dispensada, porém, como vemos no Gráfico 5, a parcela de pensões concedidas somente para a mulher (6\%) é bem pequena dentro do volume de processos abarcado nesses totais:

GRÁFICO 5 - QUEM RECEBEU PENSÃO ALIMENTÍCIA

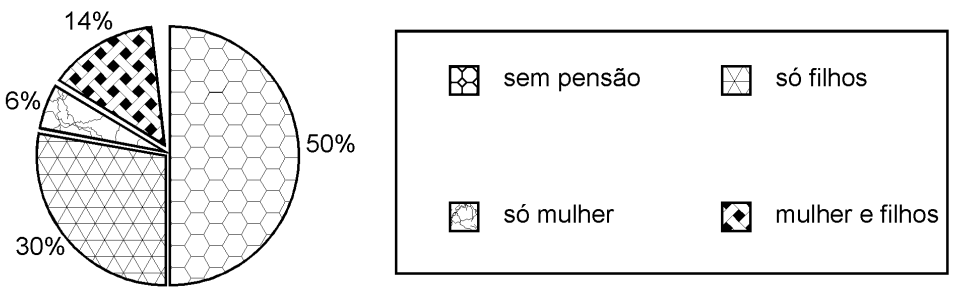

Assim, nem só de maridos provedores e de mulheres submissas se constituía o universo conjugal representado nos processos pesquisados. Mulheres chefes de família emergem das descrições, algumas como uma aguda (e 
${ }^{54}$ Processo 7.605, de 18.08.1978.

${ }^{55}$ Processo 925/80, de 05.12.1980. sofrida) declaração de independência, exemplo da história da professora primária que solicitava o divórcio e informava: "o requerido, após o nascimento do filho, mudou o seu comportamento, não mais querendo trabalhar, maltratando a suplicante com injúrias graves". $\mathrm{E}$, antes de dois anos de casados,

[...] abandonou o lar, sem, até a presente data, haver voltado ou dado sinal de vida. [...] Que a proponente está adquirindo uma casa com o produto do seu trabalho, financiada pelo Banco Sul Brasileiro, sem esforço do marido que sempre esteve ausente, eis que sua outorga foi suprida judicialmente, por isso não Ihe cabe a meação do que está pago. ${ }^{54}$

No relatório de outro processo o juiz decidiu sobre a pensão alimentícia de modo que a responsabilidade fosse dividida igualmente:

[...] Assim, os alimentos devem ser fixados de tal sorte que não signifiquem garantias à ociosidade, já que a vida moderna exige a colaboração mútua dos cônjuges, e o dever de alimentar não pode conduzir ao sacrifício de apenas uma das partes [...], não se exonerando o marido do dever de prestar alimentos pelo fato de exercer a mulher função remunerada. ${ }^{55}$

O termo "vida moderna" sugere a incorporação de novos arranjos no cotidiano das famílias. A mulher/mãe exerce função remunerada e não quer mais ser dependente do marido, nem deve receber "garantias à ociosidade", insinuavam as palavras do juiz de direito, definindo nas entrelinhas novas atribuições da mulher como colaboradora do marido na sociedade conjugal e a responsabilidade de ambos com o sustento dos filhos.

Houve um caso em que o juiz, depois de interpelar a requerente e as testemunhas do processo, relatou suas impressões na sentença de forma um tanto inusitada. Dizia:

[...] Vítima de eclâmpsia no último parto, escapou graças aos insondáveis desígnios da Providência e à solidariedade dos amigos. Não obstante com problemas cardíacos, continuou pagando com seus próprios recursos o financiamento de sua casa [...]. Foi, sem dúvida que ainda o é, a A., uma mulher forte. ${ }^{.6}$

Os exemplos se sucedem:

[...] Que desconhece o motivo que levou seu marido a tomar esta atitude, e com o seu ato veio trazer, naquela oportunidade problemas incalculáveis, principalmente de ordem moral e econômica, depois de ter convivido com o mesmo nove anos. [...] os longos anos de luta e trabalho em que teve para criar 
${ }^{57}$ Processo 7.466, de 30.06.1978.

${ }^{58}$ Processo 145/80, de 17.03.1980.

${ }^{59}$ Processo 536/79, de 29.08.1979.

e educar os filhos [...] Já criou os filhos sozinha, por isso desiste de pedir pensão alimentícia. ${ }^{57}$

Outro casal que efetuava ação de divórcio direto consensual declarava "que a mulher dispensa alimentos do marido, uma vez que está empregada e ganha o suficiente para manter-se com dignidade". ${ }^{58} \mathrm{E}$, no caso seguinte, de conversão em divórcio consensual, ficando os três filhos com a mãe, declarava que "[...] o encargo de criação e educação dos filhos toca à esposa que é o cônjuge que está no momento em melhores condições econômicas". ${ }^{59}$ São muitos os casos, e num deles constava

[...] que o marido contribuirá para a manutenção da criança com a importância de $\mathrm{Cr} \$ 300,00$, caso V. Exa. não permita seja dispensado da pensão, uma vez que no momento não exerce nenhum trabalho remunerado, pois que a mantença e educação da menor ficará ao encargo da mulher. ${ }^{60}$

Em estudos efetuados em documentos do século XIX sobre casamentos no Brasil, Eni Samara constata que nem sempre os padrões de comportamento e moralidade prescritos eram seguidos à risca ${ }^{61}$ e Joana Pedro faz constatação semelhante, observando as "imagens idealizadas", divulgadas através dos jornais de Desterro (Florianópolis antiga) do começo do século XX, como modelos para homens e mulheres, em que estas "não encontraram, necessariamente, nem correspondência, nem ressonância na experiência concreta na execução dos papéis no dia-a-dia". ${ }^{62}$ Homens e mulheres presentes neste estudo pertencem a um período histórico em que "a luta pela emancipação da mulher se fortaleceu, encontrando outros significados e recolocando as mulheres num ponto de discussão mais independente", reflete Eva Gavron. ${ }^{63}$ Os papéis estavam em constante reconstrução, e os processos ajudavam a revelar essa realidade vivida entre os casais presentes nos autos judiciais.

Porém, a mulher/mãe que, a partir da década de 1960, passou a reivindicar com mais intensidade seu direito a exercer uma função fora do lar, no espaço público ocupado prioritariamente pelos homens e que, na década de 1970, já ocupava boa parte dos postos de trabalho, embora frequentemente em situações de desigualdade, diga-se, continuou a ser cobrada quanto ao sentimento de maternidade, entendido como "natural" e desejado por todas as mulheres, pelas instâncias detentoras de saber e de poder, representado pelas visões de mundo construídas pelo universo masculino, entre eles o saber jurídico, atravessado pelos outros saberes (médicos, eclesiásticos, sociológicos, psiquiátricos etc.). 
${ }^{64}$ Processo 606/79, de 01.10.1979.

${ }^{65}$ Processo 7374 , de 30.05.1978.

${ }^{67}$ Processo 42/80, de 11.02 .1980$.

Assim, o cálculo elaborado a partir das anotações verificadas nos processos mostra que a guarda dos filhos foi concedida em sua quase totalidade para as mães (87\%), de maneira geral, sem que isso tenha demandado contestações. A guarda dos filhos não era concedida para a mãe por algum motivo especial, como, por exemplo, o abandono do lar, quando esta deixava os filhos com o marido. Nesse caso, configura-se um desses motivos em que a guarda ficava com o pai (1 1\%) ou outra pessoa (em torno de $2 \%$, geralmente para os avós maternos ou paternos).

Foram poucos os casos encontrados em que o pai insistiu na guarda dos filhos. Quando a mãe abandava 0 lar e o pai obtinha a guarda dos filhos, geralmente eram os avós paternos que cuidavam dos netos, ou até terceiros, como no caso a seguir descrito: as testemunhas confirmaram o abandono, ou seja, que os filhos ficaram com ele e informaram "que a menina está com um tio; um dos filhos vive com o patrão do A., e outro está com ele, morando na casa de um cunhado do A.; que o depoente considera o A. excelente pessoa, bom profissional, trabalhador e honesto; que ninguém sabe o paradeiro da Ré". ${ }^{64}$ Por outro lado, o caráter do homem, para ser considerado apto a ser pai, incluía os predicados de "trabalhador e honesto", uma honestidade diferente da que era cobrada da mulher, como veremos a seguir.

[...] Citada por edital, a R. não acudiu a citação. [...] além de ultrajar o seu marido, não respeitou o próprio lar, porquanto foi nele que se encontrava com seu amante, para os colóquios amorosos.[...] la, no dizer das testemunhas, para o quarto da empregada, onde permanecia longas horas com o seu amante. ${ }^{65}$

Quanto ao marido, fora descrito da seguinte maneira, exaltando suas qualidades convenientes ao papel masculino socialmente prescrito:

[...] E este, esposo fiel, pai dedicadíssimo, chefe de família exemplar, correto em seus negócios, em nada contribuiu para tal situação, tendo sido ofendido pelo procedimento ultrajante, indigno, condenável da $\mathrm{R}$. [...] ficando os filhos [...] sob guarda do pai, que é cônjuge inocente [...], perdendo a R. o direito de usar o nome de seu marido. ${ }^{66}$

Segue outro caso que decretava condenação ao comportamento da mãe: "[...] pois além da Ré ter abandonado o lar sem motivos, nunca cumpriu o sublime dever de mãe, pois deixou suas filhas com seis e sete anos, respectivamente". ${ }^{67}$ No caso seguinte, o advogado do requerente informava que marido e mulher estavam separados desde 1975 e que, "Quando do abandono do domicílio conjugal, 
${ }^{68}$ Processo $38 / 84$, de 17.01.1984.

${ }^{69}$ Processo 356/80, de 16.05.1980.

a Ré levou consigo a filha [...], para um mês depois devolvêla, pois desejava liberdade". ${ }^{68}$ A filha (juntamente com outros dois filhos do casal) ficou sob a guarda do pai, que havia constituído nova família. Nesse caso, a mãe compareceu em juízo e o processo foi transformado em consensual. As visitas à filha ficaram estipuladas para o último sábado de cada mês, entre 9 e 17 horas (o pai morava em outra cidade). Esse pode ser considerado um fato pouco comum, ou seja, a mãe deixou a filha com o marido e assumiu o fato sem medo de se expor, pois disse, explicitamente, "quero liberdade" (segundo transparece na narrativa do processo), e o marido, aparentemente, respeitava esse desejo dela.

Num outro processo, o divórcio ocorreu sem problemas, o filho ficou com a mãe, o pai pagava pensão, visitava o filho, enfim, dentro da conformidade social e jurídica. Chamou atenção uma carta explicativa que a mãe encaminhara ao juiz para evitar possíveis problemas futuros com o ex-marido informando que ela estaria se deslocando semanalmente para o Rio Grande do Sul para cursar o mestrado em pedagogia. Dizia que voltaria todos os fins de semana a Florianópolis para ficar com o filho, e seu advogado argumentava:

[...] Saliento, por oportuno, que o curso que irá iniciar somente poderá trazer lucros e venturas à Requerente e seu filho, além de uma vida mais suave, pois que terá condições de aumentar o seu ganho mensal e, assim, poderá mais facilmente atender a todas as necessidades da criança, tanto intelectual como financeira (04.01.78). ${ }^{69}$

Podemos inferir que estamos diante de perfis de mulheres que falam de seu tempo, que expressam suas vontades, embora ainda de maneira um pouco indefinida, divididas entre valores antigos e novos, pressionadas a cumprir papéis que já não aceitam como naturais, que querem ter os mesmos direitos que os homens e que precisam ser entendidas inserindo-se "na dinâmica das transformações

${ }^{70}$ Maria Izilda Santos de MATOS, 1997, p. 107.

${ }^{71}$ Roger CHARTIER, 2002, p. 97. sociais, econômicas, políticas e culturais" de sua época. ${ }^{70}$

Vimos como os discursos jurídicos utilizam, nas justificativas para este ou aquele caso, prescrições e normatizações de papéis de gênero. O discurso articulado pelos advogados que representam seus clientes perante o poder judicial, apropriando-se dos estereótipos em que para os homens cabia a responsabilidade maior de ser o provedor e para os que fugiam a essa responsabilidade - abandonando o lar - eram as mulheres abandonadas que solicitavam o divórcio alegando privações e dificuldades para o sustento dos filhos, reafirma o papel de homem/provedor. "Inscrita nas práticas e nos fatos, organizando a realidade e o cotidiano, a diferença sexual é sempre construída pelos discursos que a fundam e a legitimam", observa Chartier. ${ }^{71}$ 
${ }^{72}$ Ver BRASIL, 2002, parte especial, livro I, títulos $\mathrm{V}$ e VI.

${ }^{73}$ BOURDIEU, 2004, p. 224.
${ }^{74}$ Eric HOBSBAWM, 2004, p. 321.
Observamos também que a separação, quando há filhos e bens, envolve um círculo maior de responsabilidades e de possibilidades de conflitos a serem administrados e recontratados. Dessa forma, as obrigações não cumpridas, de homens e mulheres como pais e mães em relação a seus filhos, transformam-se em acusações fundamentadas na quebra dos deveres matrimoniais entre os quais está o "sustento, guarda e educação dos filhos" 72 que, inseridas na lógica dos discursos jurídicos, ensejam lutas travadas entre advogados de lados opostos no momento do confronto judicial que exploram as "regras possíveis", salienta Bourdieu, e as utilizam "como armas simbólicas, para fazerem triunfar a sua causa". ${ }^{73}$

Embora as informações contidas nos processos não tragam dados precisos sobre a classe social de divorciandos e divorciandas, uma parcela significativa de mulheres e homens apresentava "atestado de pobreza", ou seja, tratava-se de pessoas de baixa renda que solicitavam isenção no pagamento de custas judiciais e encaminhavam seus pedidos de divórcio através de advogados que atuavam gratuitamente, ligados ao curso de direito da Universidade Federal de Santa Catarina. Desse modo, no ano de 1978, do total de 102 processos, 32 apresentaram atestado de pobreza. Em 1979, foram 54 de 131. Em 1980, foram 62 de 134. Em 1981, foram 40 de um total de 123. Certamente esse fato se deve à situação de novidade que a Lei do Divórcio propiciava aos casais que desejavam regularizar sua situação familiar perante a sociedade e que, se tivessem que arcar com as despesas do processo, provavelmente não teriam condições financeiras. Por outro lado, para a universidade era uma forma de proporcionar um aprendizado importante aos professores e aos alunos sobre as novas práticas jurídicas no ramo do Direito de Família introduzidas com a Lei n. 6.515/77.

Como vemos, trata-se de uma percentagem de processos a ser considerada relevante, principalmente por haver, de certo modo, a ideia de que o divórcio estava sendo instituído para a classe média emergente, de que essa prática estaria restrita a uma população de poder aquisitivo elevado (compreensível se levarmos em conta os custos do processo) e, por outro lado, a uma parcela de pessoas com um nível intelectual também elevado, ignorando que as ideias e as práticas sociais novas circulavam em todos os meios e, não podemos esquecer, falamos aqui de um período em que essa circulação de "uma cultura jovem global", propiciada pela expansão dos meios de comunicação de massa, enfatizada por Hobsbawm, ${ }^{74}$ estava, poderíamos dizer, em seu ciclo mais intenso, um tempo em que as rupturas com antigos dogmas morais e costumes fizeram 
${ }^{75}$ Ver MATOS, 1997, p. 102.

${ }^{76}$ Processo 561/79, de 16.08.1979. parte do cotidiano de mulheres e homens de todas as classes sociais, de diferentes manifestações culturais, ultrapassando limites, transformando relações, quebrando tabus.

Seria temerário querer estipular em que "grau" essas transformações foram assimiladas nos diversos grupos sociais, já que se trata de uma situação bastante subjetiva e não facilmente mensurável, especialmente quando tratamos de dados apenas sutilmente "revelados" por meio da pesquisa. E, talvez, possamos contar com a cumplicidade de uma pesquisadora que reencontrou nos arquivos do Judiciário a descrição de personagens de sua infância e adolescência, que fazem parte da história das famílias e das mudanças que essas famílias vivenciaram naquele período de rebeldia e contestação.

Assim, ao longo dessas páginas pudemos perceber as novas configurações familiares legitimadas pela Lei do Divórcio como um reflexo das mudanças que já perpassavam as relações conjugais, dentro de um processo que representou uma verdadeira revolução nas famílias brasileiras ocorrida com ênfase na segunda metade do século XX. Refletiam, por outro lado, o intenso movimento de novas ideias, novos desejos, novos sentimentos, novas visões de mundo que circulavam na sociedade da época, quebrando paradigmas e rompendo dogmas longamente estabelecidos pela moral religiosa e pela ordem liberal conservadora.

Homens e mulheres entrevistos nos fragmentos de petições, contestações e sentenças nos permitem "descortinar as estruturas do cotidiano" 75 e revelam alguns indícios de que o vivido nem sempre estava de acordo com os papéis preestabelecidos, são apenas perfis sutilmente desenhados pelos discursos jurídicos que certamente representam cada um "no seu modo peculiar de ser"76 e as diferentes versões possíveis para o mesmo fato.

A lógica da reciprocidade, rompida na separação do casal, coloca homens e mulheres - ex-maridos e exesposas - diante da parcela indissolúvel do contrato de casamento, na figura dos filhos menores ou incapazes. A responsabilidade jurídica da "proteção da pessoa dos filhos" não cessa com a homologação do divórcio e os convoca a formalizar novos compromissos, firmados de acordo com o "dever de sustento, guarda e educação" da prole. Tais compromissos são controlados pelo Estado por meio de inúmeros instrumentos legais, dos quais o Estatuto da Criança e do Adolescente (1990) talvez seja o exemplo maior.

O ano de 1977 ficou marcado na história do Direito de Família no Brasil, avaliam os juristas (e outros especialistas). A Lei do Divórcio permitiu a recomposição familiar para aqueles que, vivendo em situações de ilegitimidade 
civil, puderam, enfim, obter sua nova identidade jurídica/ civil: em nome da lei, divorciados. E divorciadas, é bom que se diga, porque era para as mulheres que a cobrança das normas de comportamento impunha interdições mais rígidas e para quem as expressões depreciativas "separada", "desquitada", "mãe solteira", "deflorada", "desonrada", "amiga”, "concubina”, “amante”, "teúda” e "manteúda", "sirigaita" e outras mais eram dirigidas, inclusive no interior dos tribunais.

As muitas leis que se sucederam nesse campo do direito mostram que o assunto não está, nem de longe, esgotado. A igualdade jurídica entre homens e mulheres, tornada preceito constitucional com a Carta Magna de 1988, ainda está a exigir novas regulamentações (vide, entre outras, a conhecida como Lei Maria da Penha) e expõe a assimetria na criação e as contradições na execução dos instrumentos de controle social.

O divórcio instituído não quebrou com a norma de constituição da família nuclear, mas a recontratou, prevalecendo os papéis naturalizados. Entretanto, foi um avanço para o momento e depois dele, pois proporcionou a possibilidade de reconstrução de afetividades, da vivência de paternidades responsáveis, de novos arranjos familiares, de outras formas de viver a sexualidade, da relação com os filhos. Outras leis foram feitas posteriormente e avançaram nos direitos e na cidadania para as mulheres, novas formas de união podem ser vividas, a opção sexual não configura mais crime. Uma mulher divorciada não mais se envergonha de declarar sua situação civil e pode fazer escolhas sem a pecha de "separada", muito embora o casamento continue a ser um desejo, mas já nem é tão cobrada se não o fizer.

Passados quase 33 anos da instituição da Lei do Divórcio, a cada ano as estatísticas mostram um crescimento significativo de pedidos de divórcio. $\mathrm{E}$, para amenizar o número de processos que se acumulam no Judiciário, o Presidente da República decretou, em janeiro de 2007, a Lei n. 11.441, simplificando a tramitação e transformando a ação judicial em apenas alteração contratual. A separação e o divórcio eram sempre judiciais e, a partir da nova lei, poderão ser consensuais e feitos também no cartório de notas, desde que estejam presentes alguns requisitos, quando consensual e para casais sem filhos menores, incapazes e litígio. Hoje, separação e divórcio passaram a ser corriqueiros e sem 'sustos', o que não significa que dores e preconceitos de gênero tenham sido abolidos. 


\section{Referências bibliográficas}

BOURDIEU, Pierre. A economia das trocas lingüísticas: o que falar quer dizer. São Paulo: EDUSP, 1996.

BOURDIEU, Pierre. A dominação masculina. Rio de Janeiro: Bertrand Brasil, 2004.

BOURDIEU, Pierre. O poder simbólico. 10. ed. Rio de Janeiro: Bertrand Brasil, 2007.

BRASIL. Código Civil. Lei n. 10.406, de 10 de janeiro de 2002. Institui o Código Civil. Disponível em: <http:// www.planalto.gov.br/ccivil/leis/2002/L10406.htm >. Acesso em: 20 fev. 2008.

CAMPOS, Antonio Macedo de. Teoria e prática do divórcio: doutrina... 2. ed. Bauru (SP): Javoli, 1984.

CARNEIRO, Nelson. A luta pelo divórcio: a síntese de uma campanha em defesa da família. São Paulo: Lampião, 1977.

CASTAÑEDA, Luzia Aurelia. "Eugenia e casamento". História, Ciência, Saúde-Manguinhos, v. 10, n. 3, 2003. Disponível em: <http://www.scielo.br/scielo.php?script=sci_arttext\& pid $=$ S0104-59702003000300006\&lng $=$ en\&nrm $=$ iso $>$. Acesso em: 14 abr. 2008.

CAVALCANTI, Ana Elizabeth Lapa Wanderley. A união estável e o novo Código Civil. Disponível em: <http:// jus2.uol.com.br/doutrina >. Acesso em: 20 fev. 2008.

CHARTIER, Roger. À beira da falésia: a história entre a incerteza e a inquietude. Porto Alegre: UFRGS, 2002.

DIGIOVANI, Rosângela. Rasuras nos álbuns de família: um estudo sobre separações conjugais em processos jurídicos. 2003. Tese (Doutorado em Ciências Sociais) “ Universidade Estadual de Campinas, Campinas, 2003.

FOLHA. Disponível em: <wwwl folha.uol.com.br>. Acesso em: 24 abr. 2008.

FOLHA DE S.PAULO. 30 Anos depois. 27 mar. 1994. p. B-1. Caderno especial.

FOLHA DE S.PAULO. 30 Anos de divórcio no Brasil. 24 jun. 2007. Caderno especial.

FOUCAULT, Michel. A ordem do discurso. 15. ed. São Paulo: Loyola, 2007.

GAVRON, Eva Lúcia. Dramas e danos: estudo das vítimas de crimes sexuais na região de Florianópolis (1964-1985). 2008. Tese (Doutorado em História) “ Universidade Federal de Santa Catarina, Florianópolis, 2008.

HOBSBAWM, Eric. A era dos extremos: o breve século XX (19141991). São Paulo: Cia. das Letras, 2004.

LOHN, Reinaldo Lindolfo. Cidade dos outros: imprensa e grupos urbanos durante a ditadura militar (Florianópolis, década de 1970). Disponível em: <www.anpuh.uepg. br/xxiii-simposio/anais/textos/>. Acesso em: 10 jun. 2008. 
MATOS, Maria Izilda Santos de. "Outras histórias: as mulheres e os estudos dos gêneros - percursos e possibilidades". In: SAMARA, Eni de Mesquita; SOHIET, Rachel; MATOS,

Maria Izilda Santos de (Orgs.). Gênero em debate: trajetórias e perspectivas na historiografia contemporânea. São Paulo: EDUC, 1997. p. 83-114.

MONTEIRO, Geraldo Tadeu Moreira. Construção jurídica das relações de gênero: o processo de codificação civil na instauração da ordem liberal conservadora do Brasil. Rio de Janeiro: Renovar, 2003.

NONNENMACHER, Marilange. "Em via de difamações: um estudo sobre os limites simbólicos construídos sobre uma rua de Florianópolis". Esboços, Florianópolis: EDUFSC, v. 10, 2002. p. 147-164.

O APÓSTOLO. Florianópolis: Cúria Metropolitana, 1951.

O APÓSTOLO. Florianópolis: Cúria Metropolitana, 1957.

PEDRO, Joana Maria. Mulheres honestas e mulheres faladas: uma questão de classe. Florianópolis: EDUFSC, 1994.

PHILLIPS, Roderick. Desfazer o nó: breve história do divórcio. Lisboa: Terramar, 1991.

PODER JUDICIÁRIO DE SANTA CATARINA. Disponível em: <http:/ /www.tj.sc.gov.br/>. Acesso em: 10 abr. 2008.

SAMARA, Eni de Mesquita. "Estratégias matrimoniais do Brasil do século XIX". Revista Brasileira de História, São Paulo: ANPUH; Marco Zero, n. 15, p. 91-105, set. 87/fev. 1988.

SANTA CATARINA. Arquivo Central do Poder Judiciário. Divisão de Arquivo e Memória Judiciária. Processos de 1977 a 1985.

SCOIT, Joan. "Gênero: uma categoria útil de análise histórica". Educação e Realidade, Porto Alegre, v. 15, n. 2, p. 522, jul./dez. 1990.

[Recebido em março de 2009

e aceito para publicação em agosto de 2009]

\begin{abstract}
Divorced, by Law: Discourses in Judicial Processes in Florianópolis (1977-1985)
Abstract: This article intends to discuss the first divorce processes (from 1977 to 1985), that were made possible by the Law 6.515, of 26.12.1977 (called the Law of Divorce), in Florianópolis, through the research made in the File and Memory Division, from the Judicial Bureau of Santa Catarina State. This research realizes how - in spite of the appellative speeches of the institutions to this juridical instance (principally the Catholic Church and the institutions connected to it), that cursed the danger of family dissolution and its traditional values - such law was created mostly to legalize already established familiar habits. It also analyzes how the couples, who had been separated for many years and had established a new union, asked for divorce with the objective of regularizing their civil situation, which had been, until that moment, at the edge of the law. Observing the juridical speeches, we noticed the reproduction of prescribed values to one and other gender, and the power relations underlying these statements.
\end{abstract}

Key Words: Process of Divorce; Juridical Discourse; Gender Relations. 